\title{
Impact of livelihood diversification of rural households on their ecological footprint in agro-pastoral areas of northern China
}

\author{
HAO Haiguang ${ }^{1}$, ZHANG Jiping ${ }^{2}$, LI Xiubin ${ }^{3}$, ZHANG Huiyuan ${ }^{1 *}$, ZHANG Qiang ${ }^{1,3}$ \\ ${ }^{1}$ Chinese Research Academy of Environmental Sciences, Beijing 100012, China; \\ ${ }^{2}$ Beijing Municipal Research Institute of Environmental Protection, Beijing 100037, China; \\ ${ }^{3}$ Institute of Geographic Sciences and Natural Resources Research, Chinese Academy of Sciences, Beijing 100101, China
}

\begin{abstract}
Human-environment relationship is a focus of academic researches and an understanding of the relationship is important for making effective policies and decisions. In this study, based on rural household survey data of Taibus Banner, Duolun county and Zhengxiangbai Banner in the Inner Mongolia autonomous region of China, we identified the impact of livelihood diversification on ecosystems in these agro-pastoral areas by using the ecological footprint theory and methodology together with the one-way analysis of variance (ANOVA) and correlation analysis methods. In 2011, the total ecological footprint of consumption (EFC) was $0.665 \mathrm{~g} \mathrm{hm}^{2}$, and the total ecological footprint of production (EFP) was $2.045 \mathrm{~g} \mathrm{hm}^{2}$, which was more than three times the EFC. The ecological footprint of arable land consumption (EFAC) accounted for a large proportion of the EFC, and the ecological footprint of grassland production (EFGP) occupied a large proportion of the EFP. Both the ecological footprint of grassland consumption (EFGC) and EFGP had a significant positive correlation with the income, indicating that income was mainly depended on livestock production and the households with higher incomes consumed more livestock products. The full-time farming households (FTFHs) had the highest EFP, ecological footprint of arable land production (EFAP), EFGP and EFGC, followed by the part-time farming households (PTFHs) and non-farming households (NFHs), which indicated that part-time farming and non-farming employment reduced the occupancy and consumption of rural households on local ecosystems and natural resources to some extent. When farming households engaged in livestock rearing, both the EFAP and EFAC became smaller, while the EFP, EFC, EFGC and EFGP increased significantly. The differences in ecological footprints among different household groups should be taken into account when making ecosystem conservation policies. Encouraging the laborers who have the advantages of participating in non-farming employment to move out of the rural areas and increasing the diversification of livelihoods of rural households are important in reducing the environmental pressures and improving the welfare of households in the study area. Moreover, grassland should be utilized more effectively in the future.
\end{abstract}

Keywords: ecological footprint; livelihood diversification; livestock rearing; non-farming employment; rural households; agro-pastoral area

Citation: HAO Haiguang, ZHANG Jiping, LI Xiubin, ZHANG Huiyuan, ZHANG Qiang. 2015. Impact of livelihood diversification of rural households on their ecological footprint in agro-pastoral areas of northern China. Journal of Arid Land, 7(5): 653-664. doi: 10.1007/s40333-015-0049-5

Human beings meet their needs and improve their welfare through continuous consumption of ecosystem services, resulting in significant impact on ecosystems during these processes (Zhen et al., 2011; Wang et al., 2013; Costanza et al., 2014). The Millennium Ecosystem Assessment (2005) concluded that, if the consumption of ecosystem services by human beings does not fundamentally change, then the pressure on ecosystems will be further strengthened and lead to the collapse of ecosystems. Rural households are the main subject of economic activities and are the basic decision-making unit in rural areas, and their production and consumption behaviors dominate the changes of ecosystems (Wang et al., 2011; Yan et al., 2011). In

*Corresponding author: ZHANG Huiyuan (E-mail: zhanghy@craes.org.cn)

Received 2014-12-22; revised 2015-02-23; accepted 2015-03-03

(C) Xinjiang Institute of Ecology and Geography, Chinese Academy of Sciences, Science Press and Springer-Verlag Berlin Heidelberg 2015 
the past few decades, land reclamation and extensive utilization of resources are considered to be the main cause of ecological degradation in agro-pastoral areas (Lorent et al., 2008; Salvati and Zitti, 2009; Zhang et al., 2014).

Alternative livelihood is an important method for reducing the pressure on ecosystems and increasing the well-being of farmers in most areas (Zhang et al., 2009; Nkemnyi et al., 2013). In China, a large number of rural laborers left the traditional agriculture and turned to the non-agricultural employment in the past two decades (Hao et al., 2013). As a result, part of the rural households transited from full-time farming to part-time farming or non-farming. Livelihood diversification is the most prominent socioeconomic phenomenon in rural areas (Ellis, 2000; Ye et al., 2009). How to assess the impacts of livelihood changes on ecosystems and natural resources becomes more and more important.

However, there are some debates on the impacts of livelihood changes on ecosystems. Taking the relationship between off-farm employment and ecosystem as an example, some researchers believe that laborers leaving the rural areas alleviates the pressures on land, and thereby contributes to the deforestation reduction, biodiversity conservation and local environmental protection (Rodríguez-Meza et al., 2004; Van der Geest et al., 2010; Wang et al., 2011). The experiences in some areas, especially in the remote mountainous areas of North America and some parts of Europe, showed that off-farm employment of rural laborers contributes to the forest transition and re-growth (Caraveli, 2000; Rudel et al., 2005; Gellrich and Zimmermann, 2007; Izquierdo et al., 2011; Li and Zhao, 2011). On the contrary, some other researchers believe that rural laborers are no longer dependent on natural resources after participating in non-farming activities, resulting in land degradation (Bilsborrow, 1992; Koulouri and Giourga, 2007).

Ecological footprint, a quantitative method of evaluating the human demand on ecosystems in the Earth, represents the total area of productive land and water required on a continuous basis to produce the resources consumed, and to assimilate the wastes produced by a specific population (Wackernagel and Rees, 1996). Since the 1990s, researchers have devel- oped a series of theories and methods about the ecological footprint and carried out a large number of ecological footprint assessments in different regions, to measure the impact of human activities on ecosystems and evaluate the sustainable development (Xu et al., 2000; Erb, 2004; Chen et al., 2010; Cheng et al., 2011; Ferng, 2011; Liu et al., 2011; Gondran, 2012; Menconi et al., 2013; WWF et al., 2013a, b). The results of these researches promoted the understanding of ecosystem consumption and natural resource occupation during socioeconomic development. In recent years, scholars have increasingly advocated researches on ecological footprint both at individual and community scales (Zhang et al., 2009; Chen et al., 2010; Zhao and Mao, 2013).

Agro-pastoral areas in the center of the Inner Mongolia autonomous region are also the typical ecologically vulnerable areas. Owing to continuous drought and irrational exploitation of natural resources, land degradation and desertification become more and more serious in these areas. Consequently, these areas become the major dust source of North China, threatening the ecological security of China (State Council of the People's Republic of China, 2011). In this study, based on the rural household survey data of Taibus Banner, Zhengxiangbai Banner and Duolun county in the Inner Mongolia autonomous region, we applied the ecological footprint tool to explore the impacts of consumption and production of rural households on ecosystems and natural resources, as well as the differences in ecological footprints among different types of livelihood of rural households.

\section{Materials and methods}

\subsection{Study area}

We selected Taibus Banner, Duolun county and Zhengxiangbai Banner $\left(41^{\circ} 35^{\prime} \mathrm{N}-43^{\circ} 15^{\prime} \mathrm{N}, 114^{\circ} 05^{\prime} \mathrm{E}-\right.$ $116^{\circ} 55^{\prime} \mathrm{E}$; $1,037-1,795$ m; Fig. 1) situated in the center of the Inner Mongolia autonomous region, China as our study area. This region is under the administration of Xilin Gol League and covers an area of 13,565 $\mathrm{km}^{2}$. The study area is situated at the northern foot of the Yinshan Mountains and the southern edge of the Hunshandake Sandy Land. The area is characterized by a temperate semi-arid continental climate, with 


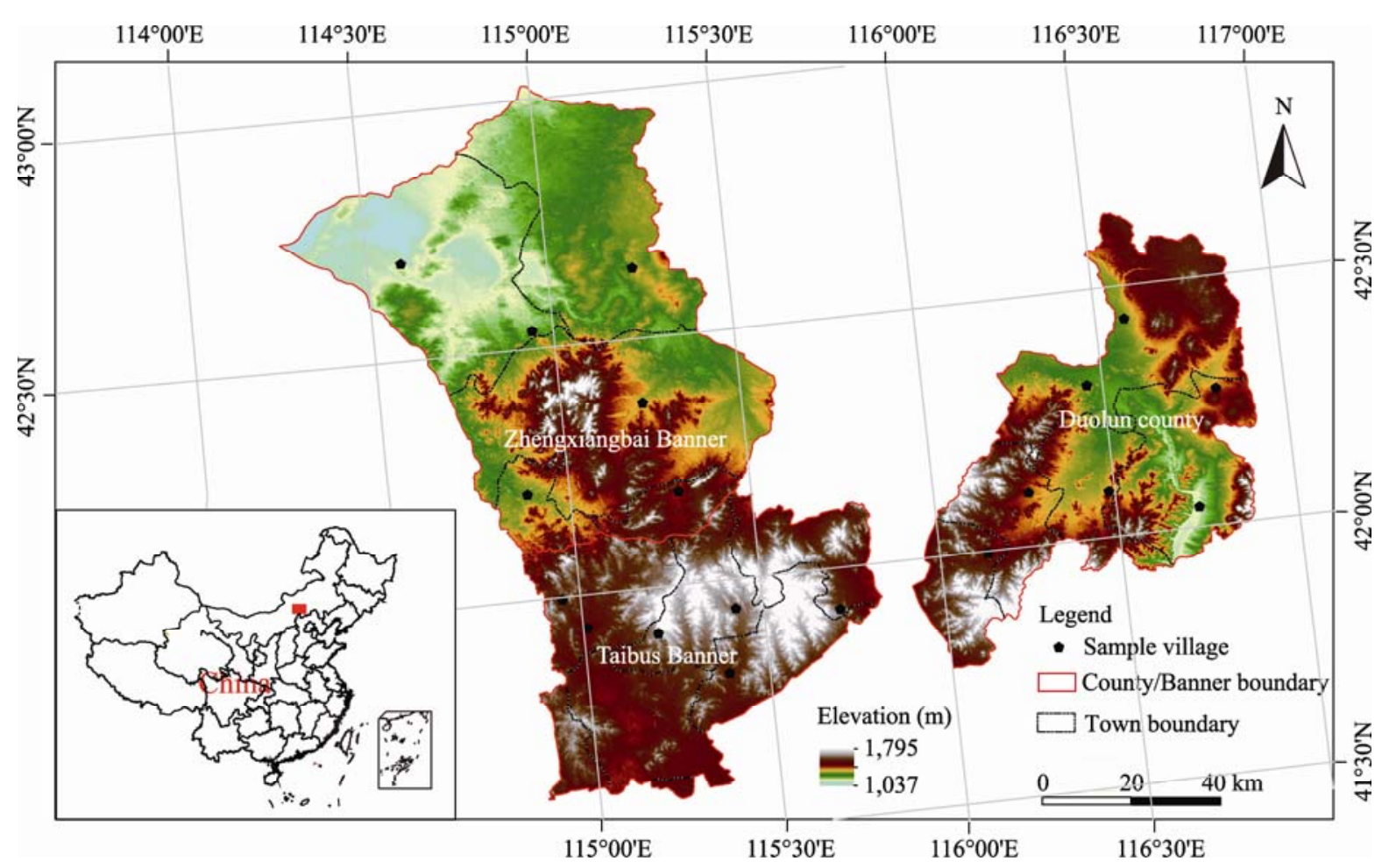

Fig. 1 Location of the study area and sample villages

the annual average temperature of about $1{ }^{\circ} \mathrm{C}$. The average annual precipitation is about $400 \mathrm{~mm}$, with most of which falling from July to September.

According to a land survey jointly undertaken by Ministry of Environmental Protection of the People's Republic of China and Chinese Academy of Sciences, areas of grassland, arable land, forest, unused land, water and construction land account for $73.84 \%$, $14.30 \%, 4.87 \%, 3.36 \%, 2.07 \%$ and $1.56 \%$ of the total study area, respectively. In the study area, grassland is mainly distributed in Zhengxiangbai Banner, accounting for $55.20 \%$ of the total grassland area; arable land is mainly distributed in Duolun county and Taibus Banner, accounting for $89.80 \%$ of the total arable land area; and forest is mainly distributed in Duolun county, accounting for $77.11 \%$ of the total forest area.

The study area belongs to the agro-pastoral region. Taibus Banner and Duolun county are dominated by agriculture, while Zhengxiangbai Banner is dominated by livestock rearing. Crops include oats, benne (sesame), wheat, potatoes, vegetables (celery, cabbage and cauliflower), peas, soybeans and kidney beans. According to the Inner Mongolia Statistical Yearbook (Inner Mongolia Autonomous Regional Bureau of
Statistics, 2012), the total yield of cereals in the study area was about $185,700 \mathrm{t}$ in 2011 and the total number of livestock was 537,400 .

The population in the study area was about 392,700 in 2011, of whom about 222,900 people living in rural areas (accounting for $56.75 \%$ of the total). Population density is estimated to be about 29 people $/ \mathrm{km}^{2}$. The average net income per capita was 6,098, 6,824 and 5,397 Chinese yuan for Taibus Banner, Duolun county and Zhengxiangbai Banner, respectively, which were all less than the national average. In rural districts, the agricultural area per capita is $0.50 \mathrm{hm}^{2}$, which is higher than the national average. According to the household survey data of this study, the main income sources for rural households are cropping, livestock husbandry and non-farming employment, accounting for $28.68 \%$, $32.17 \%$ and $20.75 \%$ of the total income, respectively.

\subsection{Data}

Rural household survey data in this study were obtained from the Rural Fixed Investigation Team of Taibus Banner, Zhengxiangbai Banner and Duolun county in 2011. We selected the target households according to the sampling method of Department of 
Rural Survey of National Bureau of Statistics (2010). First, we sorted the data of address codes of agricultural census in all villages under the jurisdiction of the surveyed county/banners, and assigned the address codes from 1 to $n$ ( $n$ is the total number of villages) to select the primary sampling units by systematic sampling with random start. Then, we ranked the primary sampling units based on the net income per capita together with the rural population data to select the secondary sampling units for income survey by systematic sampling with random start. Finally, we used the sorted address codes of households to select the survey households in each village and calculated the sampling interval by systematic sampling with random start, and subsequently 10 sample households were selected for each village. The selected samples need to meet the requirement of representativeness. This required that the acceptance error should not exceed to $\pm 3 \%$, with the confidence of probability as $95 \%$. A total of 190 sample rural households were selected, with 60 in Taibus Banner, 60 in Zhengxiangbai Banner and 70 in Duolun county. Within these 190 households, the total population and the number of laborers were 634 and 520, respectively.

The survey in this study covered the basic information of rural households, agricultural production structure, income and income sources, consumption and expenditure, sale of products, purchase of goods, laborers and employment. Table 1 shows the basic information for the rural households. In addition, we also conducted investigation in the study area in 2011 and 2012 to understand the local socioeconomic and natural conditions, ecological environment, agricultural production, and daily consumption of farmers and herdsmen. To calculate the ecological footprint of rural households, we collected the data of global average yield for each crop from the UN Food and Agriculture Organization (http://faostat3.fao.org/home/E) and related reference (Xu et al., 2000).

During the survey period, we found that livelihood diversification was a prominent phenomenon in the study area. Farmers are mainly engaged in three kinds of activities: cropping, livestock rearing and non-farming employment. Rural households can be classified into different types based on income structure or working time allocated to different activities (Zhou et al., 2001; Zhang et al., 2008). As the income can represent both the economic situation and employments, we classified the 190-surveyed rural households into three groups according to the proportion of income from non-farming employment to the total income, i.e. full-time farming households (FTFHs), part-time farming households (PTFHs) and non-farming households (NFHs). The proportions of income from non-farming employment to the total income were less than $20 \%$ for FTFHs, more than $20 \%$ and less than $80 \%$ for PTFHs, and equal to or more than $80 \%$ for NFHs.

Table 1 Descriptive statistics of the 190-surveyed rural households

\begin{tabular}{|c|c|c|c|c|}
\hline Statistic parameter & Min. & Max. & Mean & SD \\
\hline Population per household & 2.00 & 6.00 & 3.34 & 0.972 \\
\hline Number of laborers per household & 1.00 & 5.00 & 2.74 & 0.851 \\
\hline Dependency ratio per household & 0.00 & 1.50 & 0.26 & 0.333 \\
\hline Age of head per household & 26.00 & 65.00 & 48.33 & 10.464 \\
\hline Total amount of arable land per household $\left(\mathrm{hm}^{2}\right)$ & 0.00 & 6.80 & 1.57 & 1.202 \\
\hline Arable land per capita $\left(\mathrm{hm}^{2}\right)$ & 0.00 & 2.83 & 0.50 & 0.448 \\
\hline Total income per household (Chinese yuan) & $1,259.40$ & $81,721.55$ & $23,261.23$ & $13,996.526$ \\
\hline Income per capita (Chinese yuan) & 419.80 & $25,080.00$ & $7,371.04$ & $4,693.689$ \\
\hline Income per laborer (Chinese yuan) & 629.70 & $58,147.10$ & $11,469.86$ & $7,566.295$ \\
\hline Proportion of income from cropping to the total income per household (\%) & 0.00 & 100.00 & 28.68 & 27.271 \\
\hline Proportion of income from livestock rearing to the total income per household (\%) & 0.00 & 99.27 & 32.17 & 31.930 \\
\hline Proportion of income from non-farming employment to the total income per household (\%) & 0.00 & 100.00 & 20.75 & 25.346 \\
\hline
\end{tabular}

Note: Dependency ratio is defined as the ratio of those typically not in the labor force (the dependent part) to those typically in the labor force (the productive part), and is used to measure the pressure on productive population. Min., minimum; Max., maximum; SD, standard deviation. 
Generally, full-time and part-time farming households would rear livestock in a typical agro-pastoral area. Therefore, we further classified the full-time and part-time farming households into three groups according to the proportion of income from livestock rearing to the income from both cropping and livestock rearing, i.e. households engaged in cropping only (CHs), households engaged in cropping and livestock rearing (CLHs), and households engaged in livestock rearing only (LHs). The proportions of income from livestock rearing to the total income were equal to or less than $20 \%$ for $\mathrm{CHs}$, more than $20 \%$ and less than $80 \%$ for CLHs, and equal to or more than $80 \%$ for LHs.

\subsection{Methods}

In terms of calculating the ecological footprint, different kinds of inputs were first converted to the corresponding actual areas of land or water needed to produce the resources or assimilate the wastes. For comparisons, these areas were then further converted to their global hectare $\left(\mathrm{g} \mathrm{hm}^{2}\right)$ equivalents by means of equivalence factors. The equivalence factor reflects the differences in productivity of land-use categories. Each resulting footprint (in $\mathrm{g} \mathrm{hm}^{2}$ ) is a standardized and productivity-weighted hectare of global average productivity. The general ecological footprint model is as follows (Xu et al., 2000; Chen et al., 2010; Liu et al., 2011; Gondran, 2012):

$$
\mathrm{EF}=\sum_{i=1}^{n}\left(e f_{i} r_{i}\right)=\sum_{i=1}^{n}\left(\frac{c_{i}}{p_{i}} r_{i}\right) .
$$

Where, EF is the per capita ecological footprint in $\mathrm{g} \mathrm{hm}^{2}$; $e f_{i}$ is the biological production area of the $i^{\text {th }}$ goods consumed in $\mathrm{hm}^{2} ; r_{i}$ is the equivalence factor; $c_{i}$ is the per capita consumption of the $i^{\text {th }}$ goods in $\mathrm{kg}$; and $p_{i}$ is the average production capacity of the $i^{\text {th }}$ goods in $\mathrm{kg} / \mathrm{hm}^{2}$.

Some researchers have updated the basis of equivalence factor (Monfreda et al., 2004; Liu and Li, 2009). The purpose of this study was to identify the differences of ecosystem occupation among different types of households during the production and consumption processes, rather than how to precisely estimate the size of the ecological footprint. Therefore, we adopted the equivalence factors of six kinds of land use types following the study of Wackernagel and Rees (1996), in which the equivalence factor for cropland and construction land is 2.82 , for forest land and energy land is 1.14, for grassland is 0.54 and for water is 0.22 . An equivalence factor of 2.82 indicates a productivity 2.82 times the average productivity of the global ecosystem. After equalization processing, all the six land types were converted to a given global average biologically productive area.

It should be emphasized that this study is intended to investigate the ecological footprint of rural households based on both consumption and production. Consumption concerns agricultural products, livestock products and fuel, while production mainly refers to agricultural production and livestock rearing. Each of these products comes from arable land, grassland and energy land. Therefore, we defined seven kinds of ecological footprints in this study, and their definitions and calculation methods were as follows.

(1) Ecological footprint of consumption (EFC), referring to the ecological space occupied by farmers in meeting their consumption demand of agricultural products, livestock products and fuel, is the sum of the ecological footprint of arable land consumption (EFAC), ecological footprint of grassland consumption (EFGC) and ecological footprint of energy land consumption (EFEC). Their relationship is shown as Eq. 2.

$$
\mathrm{EFC}=\mathrm{EFAC}+\mathrm{EFGC}+\mathrm{EFEC} .
$$

(2) EFAC refers to the productive arable land occupied by farmers in meeting their consumption demand of agricultural products. The agricultural products refer to the products from arable land, such as wheat, oat, rice, benne, rapeseed, potatoes, beans and vegetables, and meat from arable land, such as pork and poultry. The specific products were selected based on situation in the study area. The formula of EFAC is as follows:

$$
\mathrm{EFAC}=\frac{c_{i \mathrm{a}}}{P_{i \mathrm{a}}} \times r_{\mathrm{a}} .
$$

Where, $i$ is the type of agricultural product; $c_{i \mathrm{a}}$ is the per capita consumption of the $i^{\text {th }}$ agricultural product; $P_{i \mathrm{a}}$ is the global average production capacity of the $i^{\text {th }}$ agricultural product; and $r_{\mathrm{a}}$ is the equivalence factor of arable land.

(3) EFGC refers to the productive grassland occupied by farmers in meeting their consumption demand 
of livestock products, such as beef, lamb and milk. EFGC can be calculated by Eq. 4 :

$$
\mathrm{EFGC}=\frac{c_{i g}}{P_{i g}} \times r_{\mathrm{g}} .
$$

Where, $i$ is the type of livestock product; $c_{i g}$ is the per capita consumption of the $i^{\text {th }}$ livestock product; $P_{\text {ig }}$ is the global average production capacity of the $i^{\text {th }}$ livestock product; and $r_{\mathrm{g}}$ is the equivalence factor of grassland.

(4) EFEC refers to the ecological space occupied by farmers in meeting their consumption demand of fuel. It can be calculated by Eq. 5 :

$$
\mathrm{EFEC}=\frac{c_{\mathrm{ie}} \times k_{i}}{P_{\mathrm{ie}}} \times r_{\mathrm{e}} .
$$

Where, $i$ is the type of fuel; $c_{i e}$ is the per capita consumption of the $i^{\text {th }}$ fuel type; $k_{i}$ is the conversion coefficient of the $i^{\text {th }}$ fuel type; $P_{i \text { e }}$ is the global average production capacity of the $i^{\text {th }}$ fuel type; and $r_{\mathrm{e}}$ is the equivalence factor of energy land.

(5) Ecological footprint of production (EFP), referring to the ecological space occupied by farmers in their agricultural production and livestock breeding processes, is the sum of the ecological footprint of arable land production (EFAP) and ecological footprint of grassland production (EFGP). Their relationship is shown as follows:

$$
\mathrm{EFP}=\mathrm{EFAP}+\mathrm{EFGP} \text {. }
$$

(6) EFAP refers to the productive arable land occupied by farmers in their agricultural production processes and can be calculated by Eq. 7 .

$$
\mathrm{EFAP}=\frac{p_{i \mathrm{a}}}{P_{i \mathrm{a}}} \times r_{\mathrm{a}} .
$$

Where, $i$ is the type of agricultural product; $p_{i \mathrm{a}}$ is the per capita production of the $i^{\text {th }}$ agricultural product; $P_{i \text { a }}$ is the global average production capacity of the $i^{\text {th }}$ agricultural product; and $r_{\mathrm{a}}$ is the equivalence factor of arable land.

(7) EFGP refers to the productive grassland occupied by farmers in their livestock breeding processes and can be calculated by Eq. 8 .

$$
\mathrm{EFGP}=\frac{p_{i g}}{P_{i g}} \times r_{g} .
$$

Where, $i$ is the type of livestock product; $p_{\text {ig }}$ is the per capita production of the $i^{\text {th }}$ livestock product; $P_{\text {ig }}$ is the global average production capacity of the $i^{\text {th }}$ live- stock product; and $r_{\mathrm{g}}$ is the equivalence factor of grassland.

\subsection{Statistic analysis}

One-way analysis of variance (ANOVA) was applied to test whether different household groups (the control variable) have significantly different ecological footprints (the observed variables). Correlation analysis was also used to test the relationship between ecological footprint and income indicators of rural households. Both analyses were conducted using SPSS statistical software.

\section{Results}

\subsection{Livelihood of rural households}

According to the classification of households, 123 households were FTFHs (accounting for $64.74 \%$ of the total), 60 households were PTFHs (accounting for $31.58 \%$ of the total) and 7 households were NFHs (accounting for $3.68 \%$ of the total). Combined with the actual experience of household survey and statistical descriptions of the 190-surveyed rural households, various types of households had typical characteristics (Table 2).

The population and dependence ratio per household within FTFHs were the highest among the three groups. Usually, there were three members in one household within the NFHs, and the householders and their partners were the chief laborers. Both laborers in each NFH have the advantages of participating in non-farming employment and they also prefer to stay in the city, so they abandon farming and work in the city all year round. Owing to high and stable wages from non-farming employment, the total income per household, income per capita and income per laborer in NFHs were the highest among the three groups.

CLHs were the main parts of the rural households in the study area (Table 3). The total amount of arable land managed by CLHs was the greatest among the three types of households, because these households grew straw to rear their livestock in winter. LHs possessed the least arable land because they mainly relied on natural pasture and lived in pastoral areas, where there was less arable land. 
Table 2 Statistic data of full-time farming, part-time farming and non-farming households

\begin{tabular}{|c|c|c|c|}
\hline Statistic parameter & FTFH & PTFH & $\mathrm{NFH}$ \\
\hline Number of households & 123 & 60 & 7 \\
\hline Population per household & 3.36 & 3.33 & 3.00 \\
\hline Number of laborers per household & 2.66 & 2.92 & 2.57 \\
\hline Dependency ratio per household & 0.31 & 0.17 & 0.21 \\
\hline Age of head per household & 47.33 & 50.42 & 48.14 \\
\hline Total amount of arable land per household $\left(\mathrm{hm}^{2}\right)$ & 1.46 & 1.84 & 1.01 \\
\hline Arable land per capita $\left(\mathrm{hm}^{2}\right)$ & 0.47 & 0.59 & 0.35 \\
\hline Total income per household (Chinese yuan) & $25,514.79$ & $18,287.57$ & $26,294.34$ \\
\hline Income per capita (Chinese yuan) & $8,149.65$ & $5,592.84$ & $8,931.49$ \\
\hline Income per laborer (Chinese yuan) & $12,771.72$ & $8,538.24$ & $13,722.51$ \\
\hline Proportion of income from cropping to the total income per household $(\%)$ & 32.20 & 24.12 & 5.93 \\
\hline Proportion of income from livestock rearing to the total income per household (\%) & 42.07 & 15.41 & 1.93 \\
\hline Proportion of income from non-farming employment to the total income per household $(\%)$ & 4.63 & 46.29 & 85.00 \\
\hline
\end{tabular}

Note: FTFH, full-time farming household; PTFH, part-time farming household; NFH, non-farming household.

Table 3 Statistic data of households engaged in cropping only, cropping and livestock rearing and livestock rearing only

\begin{tabular}{|c|c|c|c|}
\hline Statistic parameter & $\mathrm{CH}$ & CLH & LH \\
\hline Number of households & 53 & 79 & 51 \\
\hline Population per household & 3.38 & 3.41 & 3.24 \\
\hline Number of laborers per household & 2.75 & 2.84 & 2.59 \\
\hline Dependency ratio per household & 0.24 & 0.25 & 0.31 \\
\hline Age of head per household & 49.72 & 50.47 & 43.61 \\
\hline Total amount of arable land per household $\left(\mathrm{hm}^{2}\right)$ & 1.61 & 1.97 & 0.97 \\
\hline Arable land per capita $\left(\mathrm{hm}^{2}\right)$ & 0.52 & 0.63 & 0.31 \\
\hline Total income per household (Chinese yuan) & $18,661.94$ & $17,717.30$ & $36,212.25$ \\
\hline Income per capita (Chinese yuan) & $5,823.44$ & $5,533.14$ & $11,612.08$ \\
\hline Income per laborer (Chinese yuan) & $9,189.54$ & $9,315.51$ & $16,867.56$ \\
\hline Proportion of income from cropping to the total income per household (\%) & 58.86 & 26.91 & 3.18 \\
\hline Proportion of income from livestock rearing to the total income per household (\%) & 2.69 & 26.51 & 75.72 \\
\hline Proportion of income from non-farming employment to the total income per household (\%) & 19.91 & 22.38 & 10.27 \\
\hline Proportion of income from cropping to the income from both cropping and livestock rearing (\%) & 95.64 & 52.12 & 4.69 \\
\hline Proportion of income from livestock rearing to the income from both cropping and livestock rearing (\%) & 4.36 & 47.88 & 95.31 \\
\hline
\end{tabular}

Note: $\mathrm{CH}$, household engaged in cropping only; CLH, household engaged in cropping and livestock rearing; LH, household engaged in livestock rearing only.

\subsection{Ecological footprint of rural households}

As shown in Table 4, the average EFC was $0.665 \mathrm{~g} \mathrm{hm}^{2}$ in the study area in 2011, and the average EFAC, EFGC and EFEC were 0.348, 0.211 and $0.106 \mathrm{~g} \mathrm{hm}^{2}$, respectively (accounting for $52.33 \%, 31.73 \%$ and $15.94 \%$ of the EFC, respectively). The average EFP was $2.045 \mathrm{~g} \mathrm{hm}^{2}$, and the average EFAP and EFGP were 0.588 and $1.457 \mathrm{~g} \mathrm{hm}^{2}$, respectively. Therefore, it was clear that EFAC accounted for a larger proportion of the EFC, and EFGP accounted for a larger proportion of the EFP. Moreover, EFP was about 3 times the EFC, EFAP was 1.7 times the EFAC, and EFGP was 6.9 times the EFGC.

\subsection{Impact of livelihood diversification on eco- logical footprint of rural households}

2.3.1 Impact of non-farming employment on ecological footprint of rural households

One-way ANOVA results indicated that ecological footprints in FTFHs, PTFHs and NFHs were significantly different (Table 5). It was clear that EFP decreases 
Table 4 Descriptive statistics of different types of ecological footprints of rural households

\begin{tabular}{ccc}
\hline Ecological footprint & Mean $\left(\mathrm{g} \mathrm{hm}^{2}\right)$ & Standard deviation $\left(\mathrm{g} \mathrm{hm}^{2}\right)$ \\
\hline EFC & 0.665 & 0.435 \\
EFAC & 0.348 & 0.219 \\
EFGC & 0.211 & 0.406 \\
EFEC & 0.106 & 0.181 \\
EFAC+EFGC & 0.559 & 0.395 \\
EFP & 2.045 & 2.091 \\
EFAP & 0.588 & 0.469 \\
EFGP & 1.457 & 2.247 \\
EFP-EFC & 1.380 & 1.872 \\
EFP-(EFAC+EFGC) & 1.486 & 1.860 \\
EFP/EFC & 3.075 & 4.004 \\
EFAP/EFAC & 1.690 & 1.680 \\
EFGP/EFGC & 6.905 & 56.357
\end{tabular}

Note: EFC, ecological footprint of consumption; EFAC, ecological footprint of arable land consumption; EFGC, ecological footprint of grassland consumption; EFEC, ecological footprint of energy land consumption; EFP, ecological footprint of production; EFAP, ecological footprint of arable land production; EFGP, ecological footprint of grassland production.

with the increases in the degrees of non-farm activities. The EFP of FTFHs was $2.622 \mathrm{~g} \mathrm{hm}^{2}$, which was higher than the average of all the households (2.045 $\mathrm{g} \mathrm{hm}^{2}$ ). The EFP of PTFHs and NFHs was 1.073 and $0.250 \mathrm{~g} \mathrm{hm}^{2}$, respectively, which were lower than the average of all the households. The EFP of FTFHs was 2.4 times that of PTFHs and 10.5 times that of NFHs. This was consistent with the observation that rural households were less dependent on arable land and grassland with the increases in the degrees of non-farming activities, resulting in a sharp decline in the ecological footprints. The differences in EFAP and EFGP of the three groups were consistent with the differences in EFP, that is, EFAP and EFGP tended to decrease as the non-farming activities increased. The EFC among the three groups was also significantly different, with the order of FTFHs $>$ NFHs $>$ PTFHs. There was no significant difference in EFAC among the three groups. EFGC decreased with the increases in the degrees of non-farming activities. Moreover, the EFEC among the three groups decreased in the order of NFHs $>$ FTFHs $>$ PTFHs.

Results of the correlation analysis among different types of ecological footprints and income indicators showed that the total income per household (or income per capita) has significant positive effect on EFC, EFGC, EFP and EFGP, but negative effect on EFAC and EFAP, suggesting that the increases in income stimulated the consumption and the income of rural household was more dependent on grassland (Table 6). Income obtained from non-farming employment had significant negative effect on EFGC, EFP and EFGP. This result was consistent with the one-way ANOVA results shown in Table 5, and indicated that non-farming employment led to less consumption and production of livestock products.

2.3.2 Impact of livestock rearing on ecological footprint of rural households

One-way ANOVA results suggested that the differences of different types of ecological footprints among CHs, CLHs and LHs were also significant (Table 7). The EFC of LHs was significantly higher than that of $\mathrm{CHs}$ and CLHs, i.e. about 1.74 times that of CHs and 1.76 times that of CLHs. The higher EFC of LHs was attributed to the higher EFGC. The EFGC of LHs was about 9.34 times that of $\mathrm{CHs}$ and 11.59 times that of CLHs. With the increases in the

Table 5 Results of one-way ANOVA on ecological footprints of full-time farming, part-time farming and non-farming households

\begin{tabular}{|c|c|c|c|c|c|}
\hline \multirow{2}{*}{ Ecological footprint } & FTFH & PTFH & $\mathrm{NFH}$ & \multirow{2}{*}{$F$} & \multirow{2}{*}{$P$} \\
\hline & \multicolumn{3}{|c|}{$\left(\mathrm{g} \mathrm{hm}^{2}\right)$} & & \\
\hline $\mathrm{EFC}$ & 0.732 & 0.534 & 0.611 & 4.382 & 0.0140 \\
\hline EFAC & 0.326 & 0.398 & 0.322 & 2.278 & 0.1050 \\
\hline EFGC & 0.300 & 0.048 & 0.045 & 9.041 & 0.0000 \\
\hline EFEC & 0.107 & 0.088 & 0.245 & 2.385 & 0.0950 \\
\hline EFP & 2.622 & 1.073 & 0.250 & 15.913 & 0.0000 \\
\hline EFAP & 0.604 & 0.597 & 0.250 & 1.921 & 0.1490 \\
\hline EFGP & 2.018 & 0.476 & 0.000 & 12.356 & 0.0000 \\
\hline
\end{tabular}

Note: $F$ and $P$ are calculated from one-way ANOVA. The mean difference is significant at $P<0.05$ level. 
Table 6 Pearson correlation analysis among different types of ecological footprints and income indicators of rural households

\begin{tabular}{|c|c|c|c|c|c|}
\hline Ecological footprint & $\begin{array}{l}\text { Total income per } \\
\text { household }\end{array}$ & Income per capita & $\begin{array}{l}\text { Non-farming income } \\
\text { per household }\end{array}$ & $\begin{array}{l}\text { Income from livestock } \\
\text { rearing per household }\end{array}$ & $\begin{array}{l}\text { Cropping income per } \\
\text { household }\end{array}$ \\
\hline $\mathrm{EFC}$ & $0.348^{* *}$ & $0.535^{* *}$ & -0.109 & $0.545^{* *}$ & $-0.185^{*}$ \\
\hline EFAC & $-0.248^{* *}$ & -0.094 & 0.059 & $-0.257^{* *}$ & 0.052 \\
\hline EFGC & $0.535^{* *}$ & $0.633^{* *}$ & $-0.187^{* *}$ & $0.756^{* *}$ & $-0.270^{* *}$ \\
\hline EFEC & -0.063 & -0.022 & 0.088 & -0.076 & 0.098 \\
\hline EFP & $0.632^{* *}$ & $0.723^{* *}$ & $-0.192^{* *}$ & $0.869^{* *}$ & $-0.184^{*}$ \\
\hline EFAP & $-0.196^{* *}$ & -0.129 & -0.024 & $-0.465^{* *}$ & $0.620^{* *}$ \\
\hline EFGP & $0.629^{* *}$ & $0.700^{* *}$ & $-0.174^{*}$ & $0.905^{* *}$ & $-0.301^{* *}$ \\
\hline
\end{tabular}

Note: ${ }^{* *}$ and ${ }^{*}$ denote significance at $P<0.01$ level and $P<0.05$ level (2-tailed), respectively.

Table 7 Results of one-way ANOVA on different types of ecological footprints of households engaged in cropping only, cropping and livestock rearing, and livestock rearing only

\begin{tabular}{|c|c|c|c|c|c|}
\hline \multirow{2}{*}{ Ecological footprint } & $\mathrm{CH}$ & $\mathrm{CLH}$ & $\mathrm{LH}$ & \multirow{2}{*}{$F$} & \multirow{2}{*}{$P$} \\
\hline & \multicolumn{3}{|c|}{$\left(\mathrm{g} \mathrm{hm}^{2}\right)$} & & \\
\hline $\mathrm{EFC}$ & 0.556 & 0.549 & 0.966 & 20.632 & 0.0000 \\
\hline EFAC & 0.332 & 0.415 & 0.265 & 8.126 & 0.0000 \\
\hline EFGC & 0.067 & 0.054 & 0.626 & 55.455 & 0.0000 \\
\hline EFEC & 0.156 & 0.080 & 0.075 & 4.042 & 0.0190 \\
\hline EFP & 0.825 & 1.504 & 4.397 & 82.211 & 0.0000 \\
\hline EFAP & 0.811 & 0.722 & 0.197 & 37.608 & 0.0000 \\
\hline EFGP & 0.014 & 0.782 & 4.201 & 116.565 & 0.0000 \\
\hline
\end{tabular}

Note: $F$ and $P$ are calculated from one-way ANOVA. The mean difference is significant at $P<0.05$ level.

intensities of livestock rearing, the EFEC of householdstended to decline. This is mainly because LHs collect animal manure as the fuel while $\mathrm{CHs}$ choose coal as the fuel.

The EFP increased when the income of households was more dependent on livestock rearing. The EFP of CHs, CLHs and LHs was 0.825, 1.504 and $4.397 \mathrm{~g}$ $\mathrm{hm}^{2}$, respectively, and the EFP of LHs was 5.33 times that of CHs and 2.92 times that of CLHs. The EFAP of CHs, CLHs and LHs was 0.811, 0.722 and $0.197 \mathrm{~g}$ $\mathrm{hm}^{2}$, respectively, while the EFGP for the three groups was $0.014,0.782$ and $4.201 \mathrm{~g} \mathrm{hm}^{2}$, respectively. So it was clear that EFAP decreased while EFGP increased with the increases in the intensities of livestock rearing.

Correlation analysis showed that income obtained from livestock rearing had significant positive effect on EFC, EFGC, EFP and EFGP, but negative effect on EFAC and EFAP (Table 6). Moreover, income obtained from cropping had significant positive effect on EFAP, but negative effect on EFC, EFGC, EFP and EFGP.

\section{Discussion}

Ecological footprint is an indicator to measure the ecosystem consumption and natural resources occupation during human activities. Irrational utilization of natural resources is considered to be the main cause for ecological degradation in agro-pastoral areas in the past few decades. To protect the vulnerable ecosystems in these areas, it is necessary for farmers to maintain the ecological footprint with reasonable size.

Comparing the mean ecological footprint of NFHs with that of FTFHs and all the households, we found that the EFC, EFAC, EFGC, EFP, EFAP and EFGP decreased markedly when households engaged fully in non-farm activities. Moreover, comparing the mean ecological footprint of PTFHs with that of FTFHs and all the households, we found that EFC, EFGC, EFEC, EFP and EFGP were all less than the average. Both of the part-time farming and completely non-farming employment reduced the occupa- 
tion and consumption of households on local ecosystems and natural resources to some extent. Some researchers have argued that sustainable 'win-win' outcomes (poverty alleviation and environmental restoration) can be largely achieved through the non-farming employment of rural laborers (Groom et al., 2010; Moran-Taylor and Taylor, 2010). Therefore, a key initiative for ecosystem conservation in ecologically vulnerable areas is to increase the non-farming employment and the livelihood diversification of rural households. Policy makers should take measures to promote the training and education of farmers and herdsmen, increase the opportunities of non-farming employment, and enhance the abilities of rural laborers to seek new livelihoods.

Policy makers also need to take full account of the needs of farmers in consumption and production. Cropping activity and livestock rearing of households mainly rely on natural resources. Livestock rearing is an important activity of rural households in agro-pastoral areas, so overgrazing is one of the main threats to the ecological security. The results of this study suggested that the ecological footprint of rural households is mainly determined by the consumption and production of livestock products. When farmers are fully engaged in livestock rearing, both the EFP and EFC increase significantly. Therefore, it can be argued that persuading households to reduce the production and consumption of livestock products is an effective approach in reducing the ecological footprint in the study area. Improving the effectiveness of resource utilization is also important in reducing the ecological footprint of households. Livestock should be reared according to the carrying capacity of grassland, or using captive breeding methods.

In this study, we calculated the EFC and EFP of rural households to explore the effects of the consumption and production of rural households on ecosystems and resources. The findings suggested that the EFP of rural households was much larger (about three times more) than the EFC in the study area, indicating that most products obtained from the ecosystems were supplied outside the study area. To protect the vulnerable ecosystems, production tasks should be reduced in this area. Ecological compensation is an environmental protection policy which intends to bal- ance the ecological protection and the livelihood of impoverished landowners. Ecological footprint has been used in the formulation of inter-regional ecological compensation (Liu et al., 2010; Xiao et al., 2011; Long and Chen, 2012; Wei and Xia, 2012). Similarly, this study also promotes the development of ecological compensation policies in agro-pastoral areas and ecologically vulnerable areas.

\section{Conclusions}

Human-environment interaction is a complicated issue. Rather than looking at environmental change as a cause of livelihood diversification of rural households, we empirically examined the impact of livelihood diversification of rural households on their natural capital demand based on the ecological footprint theory and methodology in this study.

In this typical agro-pastoral region, farmers are mainly engaged in three kinds of activities, i.e. cropping, livestock rearing and non-farming employment. Livelihood diversification of rural households has been a prominent phenomenon in this area. The results showed that the EFP of rural households was more than three times the EFC. In particular, the EFGP was about seven times the EFGC. Non-farming employment of rural households led to a decrease in the EFP, EFAP, EFGP and EFGC, indicating that participating in non-farming activities can mitigate the occupation and consumption of rural households on local ecosystems and natural resources. When farmers engage in livestock rearing, particularly when they are fully engaged in livestock rearing, the EFAC and EFAP of these households are small while the EFGC and EFGP are large, resulting in a larger total ecological footprint.

Policy makers should take measures to increase the non-farming employment and the transition of livelihoods of rural households in agro-pastoral areas to protect the vulnerable ecosystems. Ecological compensation policies also need to be developed in agro-pastoral areas in order to balance the ecological protection and the livelihood of impoverished landowners. Furthermore, natural resources, especially the grassland, should be utilized more effectively to reduce the ecological footprint of rural households. 


\section{Acknowledgements}

This study was supported by the National Natural Science Foundation of China (41161140352, 41471092).

\section{References}

Bilsborrow R E. 1992. Population growth, internal migration, and environmental degradation in rural areas of developing countries. European Journal of Population, 8(2): 125-148.

Caraveli H. 2000. A comparative analysis on intensification and extensification in Mediterranean agriculture: dilemmas for LFAs policy. Journal of Rural Studies, 16(2): 231-242.

Chen D D, Gao W S, Chen Y Q, et al. 2010. Ecological footprint analysis of food consumption of rural residents in China in the latest 30 years. Agriculture and Agricultural Science Procedia, 1: 106-115.

Cheng K, Pan G X, Smith P, et al. 2011. Carbon footprint of China's crop production - an estimation using agro-statistics data over 1993-2007. Agriculture, Ecosystems \& Environment, 142(3): 231-237.

Costanza R, de Groot R, Sutton P, et al. 2014. Changes in the global value of ecosystem services. Global Environmental Change, 26: $152-158$.

Department of Rural Survey of National Bureau of Statistics. 2010. 2010 China Yearbook of Rural Household Survey. Beijing: China Statistic Press, 4-6. (in Chinese)

Ellis F. 2000. Rural Livelihoods and Diversity in Developing Countries. Oxford: Oxford University Press, 56-74.

Erb K H. 2004. Actual land demand of Austria 1926-2000: a variation on ecological footprint assessments. Land Use Policy, 21(3): 247-259.

Ferng J J. 2011. Measuring and locating footprints: a case study of Taiwan's rice and wheat consumption footprint. Ecological Economics, 71: 191-201.

Gellrich M, Zimmermann N E. 2007. Investigating the regional-scale pattern of agricultural land abandonment in the Swiss mountains: a spatial statistical modelling approach. Landscape and Urban Planning, 79(1): 65-76.

Gondran N. 2012. The ecological footprint as a follow-up tool for an administration: application for the Vanoise National Park. Ecological Indicators, 16: 157-166.

Groom B, Grosjean P, Kontoleon A, et al. 2010. Relaxing rural constraints: a 'win-win' policy for poverty and environment in China? Oxford Economic Papers, 62(1): 132-156.

Hao H G, Li X B, Zhang J P. 2013. Impacts of part-time farming on agricultural land use in ecologically-vulnerable areas in North China. Journal of Resources and Ecology, 4(1): 70-79.

Inner Mongolia Autonomous Regional Bureau of Statistics. 2012. Inner Mongolia Statistical Yearbook. Beijing: China Statistics Press, 696-705. (in Chinese)

Izquierdo A E, Grau H R, Aide T M. 2011. Implications of rural-urban migration for conservation of the Atlantic Forest and urban growth in Misiones, Argentina (1970-2030). Ambio, 40(3): 298-309.

Koulouri M, Giourga C. 2007. Land abandonment and slope gradient as key factors of soil erosion in Mediterranean terraced lands. Catena, 69(3): 274-281.
Li X B, Zhao Y L. 2011. Forest transition, agricultural land marginalization and ecological restoration. China Population, Resources and Environment, 21(10): 91-95. (in Chinese)

Liu D, Feng Z M, Yang Y Z, et al. 2011. Spatial patterns of ecological carrying capacity supply-demand balance in China at county level. Journal of Geographical Sciences, 21(5): 833-844.

Liu M C, Li W H. 2009. The calculation of China's equivalence factor under ecological footprint mode based on net primary production. Journal of Natural Resources, 24(9): 1550-1559. (in Chinese)

Liu Q, Peng X C, Zhou L X, et al. 2010. Quantitative research on ecological compensation among every city of Guangdong Province based on ecological footprint and ecological carrying capacity. Meteorological and Environmental Research, 1(6): 82-85.

Long K S, Chen L G. 2012. Theory construction and its application to ecological environment compensation based on ecological land rent. Journal of Natural Resources, 27(12): 2048-2056. (in Chinese)

Lorent H, Evangelou C, Stellmes M, et al. 2008. Land degradation and economic conditions of agricultural households in a marginal region of northern Greece. Global and Planetary Change, 64(3): 198-209.

Menconi M E, Stella G, Grohmann D. 2013. Revisiting the food component of the ecological footprint indicator for autonomous rural settlement models in Central Italy. Ecological Indicators, 34: 580-589.

Millennium Ecosystem Assessment. 2005. Ecosystems and Human Well-being: Synthesis. Washington DC: Island Press, 87-108.

Monfreda C, Wackernagel M, Deumling D. 2004. Establishing national natural capital accounts based on detailed ecological footprint and biological capacity assessments. Land Use Policy, 21(3): 231-246.

Moran-Taylor M J, Taylor M J. 2010. Land and leña: linking transnational migration, natural resources, and the environment in Guatemala. Population and Environment, 32(2-3): 198-215.

Nkemnyi M F, de Haas A, Etiendem N D, et al. 2013. Making hard choices: balancing indigenous communities livelihood and Cross River gorilla conservation in the Lebialem-Mone Forest landscape, Cameroon. Environment, Development and Sustainability, 15(3): 841-857.

Rodríguez-Meza J, Southgate D, González-Vega C. 2004. Rural poverty, household responses to shocks, and agricultural land use: panel results for El Salvador. Environment and Development Economics, 9(2): 225-239.

Rudel T K, Coomes O T, Moran E, et al. 2005. Forest transitions: towards a global understanding of land use change. Global Environmental Change, 15(1): 23-31.

Salvati L, Zitti M. 2009. The environmental "risky” region: identifying land degradation processes through integration of socio-economic and ecological indicators in a multivariate regionalization model. Environmental Management, 44(5): 888-898.

State Council of the People's Republic of China. 2011. Major function-oriented zone planning of China. The State Council of the People's Republic of China, Beijing, China. [2011-06-08]. http://www.gov.cn/zhengce/content/2011-06/08/content_1441.htm. (in Chinese)

Van der Geest K, Vrieling A, Dietz T. 2010. Migration and environment in Ghana: a cross-district analysis of human mobility and vegetation dynamics. Environment and Urbanization, 22(1): 107-123. 
Wackernagel M, Rees W E. 1996. Our Ecological Footprint: Reducing Human Impact on the Earth. Gabriola Island: New Society Publishers, 59-88.

Wang C C, Yang Y S, Zhang Y Q. 2011. Economic development, rural livelihoods, and ecological restoration: evidence from China. Ambio, 40(1): 78-87.

Wang D S, Zheng H, Ouyang Z Y. 2013. Ecosystem services supply and consumption and their relationships with human well-being. Chinese Journal of Applied Ecology, 24(6): 1747-1753. (in Chinese)

Wei X Y, Xia J X. 2012. Ecological compensation for large water projects based on ecological footprint theory: a case study in China. Procedia Environmental Sciences, 13: 1338-1345.

WWF (World Wildlife Fund), GFN (Global Footprint Network), ZSL (Zoological Society of London). 2013a. Living planet report 2012: biodiversity, biocapacity and better choices. WWF International, Gland, Switzerland. https://fenix.tecnico.ulisboa.pt/downloadFile/ 3779579969611/living_planet_report_2012.pdf.

WWF (World Wildlife Fund), IGSNRR (Institute of Geographic Sciences and Natural Resources Research, Chinese Academy of Sciences), GFN (Global Footprint Network), et al. 2013b. China ecological footprint report 2012: consumption, production and sustainable development. WWF International, Gland, Switzerland. http://www.doc88.com/p-9495607 83610.html.

Xiao J H, Chen S J, Yu Q D, et al. 2011. A study on ecological compensation standard for Zaoshi Water Conservancy Project based on the idea of ecological footprint. Acta Ecologica Sinica, 31(22): 6696-6707. (in Chinese)

Xu Z M, Zhang Z Q, Cheng G D. 2000. The calculation and analysis of ecological footprints of Gansu Province. Acta Geographic Sinica,
55(5): 607-616. (in Chinese)

Yan J Z, Wu Y Y, Zhang Y L. 2011. Adaptation strategies to pasture degradation: gap between government and local nomads in the eastern Tibetan Plateau. Journal of Geographical Sciences, 21(6): 1112-1122.

Ye J Z, Wang Y H, Long N. 2009. Farmer initiatives and livelihood diversification: from the collective to a market economy in Rural China. Journal of Agrarian Change, 9(2): 175-203.

Zhang J, Niu J M, Bao T, et al. 2014. Human induced dryland degradation in Ordos Plateau, China, revealed by multilevel statistical modeling of normalized difference vegetation index and rainfall time-series. Journal of Arid Land, 6(2): 219-229.

Zhang L P, Zhang Y L, Yan J Z, et al. 2008. Livelihood diversification and cropland use pattern in agro-pastoral mountainous region of eastern Tibetan Plateau. Journal of Geographical Sciences, 18(4): 499-509.

Zhang Y B, Wang M J, Li J Q, et al. 2009. The impact of ecological compensation on farmers' ecological footprint: an empirical study on Giant Panda habitat. Acta Ecologica Sinica, 29(7): 3569-3575. (in Chinese)

Zhao X Y, Mao X W. 2013. Comparison environmental impact of the peasant household in han, zang and hui nationality region: case of Zhangye, Gannan and Linxia in Gansu Province. Acta Ecologica Sinica, 33(17): 5397-5406. (in Chinese)

Zhen L, Liu X L, Wei Y J, et al. 2011. Consumption of ecosystem services: a conceptual framework and case study in Jinghe Watershed. Journal of Resources and Ecology, 2(4): 298-306.

Zhou Z Y, Sumner D A, Lee H. 2001. Part-time farming trends in China: a comparison with the Japanese and Korean experience. Comparative Economic Studies, 43(3): 99-132. 